RESEARCH ARTICLE

\title{
Effect of Organic Amendments on Growth, Nutrient Uptake Pattern and Yield of ginger (Zingiber officinale Rosc.)
}

\author{
Chitra. R and Vinothini. L \\ Department of Spices and Plantation Crops \\ Horticultural College and Research Institute, Tamil Nadu Agricultural University, Periyakulam - 625604, Tamil Nadu, India
}

\begin{abstract}
The high yield of ginger is function of adequate and timely supply of plant nutrients. Among the various agronomic technologies influencing the production of ginger, nutrition is found to exert a great influence on growth and yield of ginger. Imbalance, low or no fertilizer application is one of the most important factors in obtaining the poor yield. Hence, the trial was taken to study the effect of organic manures (FYM, neem cake, vermicompost, Azospirillum) and biostimulants (panchakavya, humic acid and PPFM) on growth, yield and nutrient uptake of ginger at Department of Spices and Plantation Crops, Horticultural College and Research Institute, Tamil Nadu Agricultural University, Coimbatore. The growth parameters like plant height, number of leaves, number of tillers and leaf area were found to be higher in the plants fed with 50\% N (FYM) $+25 \% \mathrm{~N}$ (Neem cake) $+25 \% \mathrm{~N}$ (Vermicompost) + Azospirillum (5kg/ha) + Panchakavya (3\%). The maximum green rhizome yield $\left(23.55 \mathrm{t} \mathrm{ha}^{-1}\right)$ was obtained with the application of $50 \%$ $\mathrm{N}(\mathrm{FYM})+25 \% \mathrm{~N}$ (Neem cake) + 25\% N (Vermicompost) + Azospirillum (5kg/ ha) + Panchakavya (3\%) per hectare. The highest uptake of nitrogen (119.06 $\left.\mathrm{kg} \mathrm{ha}^{-1}\right)$ and potassium (197.56 $\mathrm{kg} \mathrm{ha}^{-1}$ ) was found in the application of 50\% $\mathrm{N}(\mathrm{FYM})+25 \% \mathrm{~N}$ (Neem cake) + 25\% N (vermicompost) + Azospirillum (5kg/ ha) + panchakavya (3\%) per hectare The maximum amount of Phosphorus uptake (14.35 kg ha-1) was recorded in the application of 50\% N (FYM) $+25 \%$ $\mathrm{N}$ (neem cake) $+25 \% \mathrm{~N}$ (vermicompost) + Azospirillum (5kg/ha) + humic acid $(0.1 \%)$. In ginger cultivation, the application of organic manures and inorganic fertilizers commonly practiced to increase the yield and quality of rhizome. Considering the world demand for organic food, the improvement of soil health, productivity and the availability of local resources, cultivation under organic farming can be encouraged.
\end{abstract}

Received : $11^{\text {th }}$ November, 2020 Revised : $21^{\text {st }}$ November, 2020 Revised : $28^{\text {th }}$ November, 2020 Accepted : $05^{\text {th }}$ December, 2020

Keywords: Bio-stimulants; Growth parameters; Ginger; Nutrient uptake; Organic manures; Yield

\section{INTRODUCTION}

Ginger is botanically known as Zingiber officinale Rosc., belongs to the family Zingiberaceae and in the natural order Scitamineae. Ginger is one among the five important major spices of India, which play on important role in national economy. Ginger is widely spread out in tropical and subtropical countries. It is a perennial herb that grows up to 3-4 feet in height with thick spreading tuberous rhizomes. It is valued as a commercial crop, which is grown for its aromatic rhizomes and primarily being used as a spice and medicine (Sharma et al., 2010). Ginger has been used as a spice and as natural additive for more than 2000 years (Bartley and Jacobs, 2000). Fresh ginger contains $80.9 \%$ moisture, $2.3 \%$ protein, $0.9 \%$ fat, $1.2 \%$ minerals, $2.4 \%$ fibre and $12.3 \%$ carbohydrates and powdered rhizome contains 3-6\% fatty oil, 9\% protein, $60-70 \%$ carbohydrates, 3-8\% crude fibre, about $8 \%$ ash, $9-12 \%$ water, $4-7.5 \%$ oleoresin and $2-3 \%$ volatile oil. It also contains minerals like iron, calcium and phosphorous and vitamins like thiamine, riboflavin, niacin and vitamin $\mathrm{C}$ and pungent substances, namely gingerol, shogaol, zingerone and paradol (Anon., 2003). The chief constituent of ginger oil from dried ginger is zingiberine (38.6\%), a sesquiterpene hydrocarbon. In traditional Chinese and Indian medicine, ginger is used to treat a wide range of ailments, including stomachaches, diarrhea, nausea, asthma and respiratory disorders (Grzanna et al., 2005).

Ginger is a long-growing crop, which needs a balanced supply of nutrients to boost its fresh rhizome yield with improved quality. Organic sources can supply the balanced nutrients. Inadequate or 
imbalanced nutrient supply is one of the major constraints in augmenting fresh rhizome yields. Combined application of different organic sources such as the farmyard manure, vermicompost and neemcake results in to high yield and quality rhizomes of turmeric (Sarma et al., 2015). It will not only be helpful for sustainable agricultural development but will also avoid chemical-based farming. Furthermore, consistent and indiscriminate use of inorganic fertilizers has caused severe damage to the soil and ecology.

In recent years, organic agriculture has been gaining considerable importance and many farmers are switching over to this traditional method of cultivation as a means to produce safe foodstuff and conserve the environment. Application of organic manures has various advantages like improving soil physical properties, water holding capacity and organic carbon content, apart from supplying good quality nutrients (Singh et al., 2009). Organic farming practice can be encouraged owing to the world demand for organic food, the improvement of soil health and productivity, and the availability of local resources. A few reports on the use of organic manures and inorganic fertilizers in ginger have also been documented (Khandkar and Nigam 1996; Singh and Singh 2007; Roy and Hare 2007). The productivity of ginger and soil fertility is declining day by day due to non-judicious and indiscriminate use of inorganic fertilizers. The information regarding the combined use of different nutrient sources in ginger cultivation in Tamil Nadu region is scanty. In the light of these observations, the present study was undertaken to investigate the comparative effect of organic manures, biofertilizers, bio-stimulants and their different combinations on yield and uptake of $\mathrm{N}, \mathrm{P}$, and $\mathrm{K}$ by ginger crop.

\section{MATERIAL AND METHODS}

A field experiment was conducted at the College Orchard, Tamil Nadu Agricultural University, Coimbatore, during 2016 - 2017. The field is located at an altitude of $426.26 \mathrm{~m}$ above MSL (mean sea level) at geographical location of $110 \mathrm{~N}$ latitude and $77^{\circ} \mathrm{E}$ longitude. The soil of the experimental field was sandy clay loam having $\mathrm{pH} 7.81$, organic carbon $0.60 \%$, available N, P205, and K20; 205.40, 56.76 and $825.79 \mathrm{~kg} \mathrm{ha}^{-1}$, respectively. The experiment was laid out in randomized block design with three replications.

Phosphorus was applied as rock phosphate at the time of planting. Potassium was applied as potassium schoenite. Nitrogen and potassium were applied in two split doses, the first dose at 40 days after planting and the second dose at 90 days after planting. The seed bits (rhizome bits) were treated with Pseudomonas @ 2g/lit for 10 min prior to planting. The healthy rhizome bits weighing about 15-20 g each were planted at a spacing of $30 \times 30$ $\mathrm{cm}$ in $3 \mathrm{~m} \times 1 \mathrm{~m}$ beds and mulched with paddy straw to conserve the moisture and facilitate germination besides suppressing weed growth in the early stage. The response of treatments was evaluated in terms of plant height, number of leaves/plant, size of leaves and number of tillers per clump at maximum growth stage (150 days after planting). The crop was harvested 8 months after planting. The yield of green ginger was recorded after washing the rhizome thoroughly. Green ginger was later soaked in warm water to facilitate the removal of skin for dry ginger production. The scrapped produce was washed and dried in the sunlight for 3-4 days to 8$10 \%$ of moisture and the cured yield was recorded. The amount of dry recovery is given based on the weight of water present in the product and is usually expressed in percent (Sahay and Singh, 1994).

\section{The treatment details are as follows,}

\begin{tabular}{|c|c|}
\hline $\begin{array}{c}\text { Experiment } \\
\text { code }\end{array}$ & Details \\
\hline $\mathrm{T}_{0}$ & $\begin{array}{l}\text { Control (Recommended dose of fertilizer 75:50:25 kg } \\
\text { NPK) }\end{array}$ \\
\hline $\mathrm{T}_{1}$ & $75 \%$ N (FYM) + 25\% N (Neem cake) + Panchakavya (3\%) \\
\hline $\mathrm{T}_{2}$ & $75 \% \mathrm{~N}(\mathrm{FYM})+25 \% \mathrm{~N}($ Neem cake) + PPFM (1\%) \\
\hline $\mathrm{T}_{3}$ & $75 \% N($ FYM $)+25 \% N($ Neem cake $)+$ Humic acid $(0.1 \%)$ \\
\hline $\mathrm{T}_{4}$ & $75 \%$ N (FYM) + 25\% N (Vermicompost) + Panchakavya (3\%) \\
\hline $\mathrm{T}_{5}$ & $75 \% N(F Y M)+25 \% N$ (Vermicompost) + PPFM (1\%) \\
\hline $\mathrm{T}_{6}$ & $75 \% N($ FYM $)+25 \% N($ Vermicompost $)+$ Humic acid (0.1\%) \\
\hline $\mathrm{T}_{7}$ & $\begin{array}{l}50 \% \mathrm{~N}(\mathrm{FYM})+25 \% \mathrm{~N}(\text { Neem cake })+25 \% \mathrm{~N}(\text { Vermicompost }) \\
+ \text { Azospirillum }(5 \mathrm{~kg} / \mathrm{ha})+\text { Panchakavya }(3 \%)\end{array}$ \\
\hline$T_{8}$ & $\begin{array}{l}50 \% \mathrm{~N}(\mathrm{FYM})+25 \% \mathrm{~N}(\text { Neem cake })+25 \% \mathrm{~N} \text { (Vermicompost) } \\
+ \text { Azospirillum }(5 \mathrm{~kg} / \mathrm{ha})+\operatorname{PPFM}(1 \%)\end{array}$ \\
\hline$T_{9}$ & $\begin{array}{l}50 \% \mathrm{~N}(\mathrm{FYM})+25 \% \mathrm{~N}(\text { Neem cake })+25 \% \mathrm{~N} \text { (Vermicompost) } \\
+ \text { Azospirillum }(5 \mathrm{~kg} / \mathrm{ha})+\text { Humic acid }(0.1 \%)\end{array}$ \\
\hline
\end{tabular}

Nutrient content of applied organic manures

\begin{tabular}{llll}
\hline Nutrient & $\begin{array}{l}\text { Farmyard } \\
\text { manure }\end{array}$ & vermicompost & Neem cake \\
\hline Organic carbon (\%) & 5.1 & 9.5 & 1.2 \\
$\mathrm{~N}(\%)$ & 0.81 & 1.50 & 5.00 \\
P205 (\%) & 0.20 & 0.31 & 0.98 \\
K20 (\%) & 0.57 & 0.52 & 2.30 \\
\hline
\end{tabular}

The nitrogen content in the leaves on the dry weight basis was estimated by the Micro Kjeldahl method (Humphries, 1956) and expressed as percent. The phosphorous content was estimated in a triple acid extract by adopting vana domolybdate phosphoric yellow color method (Jackson, 1973) and expressed in percent. The potassium content was estimated by reading in the flame photometer values of triple acid extract (Jackson, 1973) and expressed in percentage. The total dry matter production and estimated nitrogen, phosphorus and potassium content, total uptake of respective nutrients were 
worked out using the formula suggested by Piper (1966). The data collected from the experiments were analyzed by adopting the procedure described by Panse and Sukhatme (1985).

\section{RESULTS AND DISCUSSION}

The important growth parameters like plant height, number of leaves and number of tillers that influence the growth and productivity of the crop are preseted in Table 1 . These growth attributes were significantly affected by different treatments. Application of 50\% N (FYM) +25\% N (Neem cake) $+25 \% \mathrm{~N}$ (Vermicompost) + Azospirillum (5kg/ha) + Panchakavya (3\%) recorded the highest plant height $(60.20 \mathrm{~cm})$ followed by application of $75 \% \mathrm{~N}$ $(F Y M)+25 \% \mathrm{~N}$ (Vermicompost) + Humic acid (0.1\%) $(57.40 \mathrm{~cm})$. The treatments $\mathrm{T} 7$ and $\mathrm{T} 6$ recorded the highest number of leaves in case of number of leaves (140.56 and 139.58 , respectively). The data on number of tillers per plant was recorded highest in the plant fed with $50 \% \mathrm{~N}$ (FYM) $+25 \% \mathrm{~N}$ (Neem cake) + 25\% N (Vermicompost) + Azospirillum (5kg/ha) + Panchakavya (3\%) (9.80). Largest leaf area per plant was observed by the application of 50\% N (FYM) +25\% N (Neem cake) + 25\% N (Vermicompost) + Azospirillum (5kg/ha) + Panchakavya (3\%) (2378.72 $\mathrm{cm} 2$ ). The results revealed that the increased morphological characters like plant height, number of leaves, number of tillers and leaf area might attribute due to the soil application of organic amendments like FYM, neem cake, vermicompost and foliar application of panchakavya. Being a fermented mixture, panchakavya enhanced the production of growth-promoting substances like auxins and gibberellins, as demonstrated by Nene (1999). The IAA and GA present in panchakavya, when sprayed many times on the plant, could have created stimuli in the plant system. The action of the growth regulators in the plant system was checked by the counteracting inhibitors and stimulation of necessary growth substances through the external application of foliar spray increases the physiological activities of growth and development, leading to enhanced height and other growth parameters. The results revealed that higher plant growth due to FYM might have influenced the physical, chemical and biological properties of soil by supplying macro and micronutrients, leading to better plant growth and development. Earlier studies by Singh et al. (2009) and Sarma et al. (2011) had also reported that the organic manures increased the growth attributes of ginger, cabbage and other crops.

The possible reason for better enhancement in plant height and number of leaves under different organic sources might be attributed due to the better proliferation of roots which helped in increased uptake of nutrients as well as plant growth hormones produced by microbes in the root zone. These findings are also in conformity with Poinker et al. (2006). FYM with narrow C: $\mathrm{N}$ ratio may produce humic acid and humic substances in the form of chelates with phosphorus. This will increase the number of tillers per plant and the same trend was studied by Sarma et al. (2015) in turmeric and Singh et al. (2009) in ginger. The increased leaf area might be due to the more significant mobilization of nutrients from vermicompost, which would have resulted in enhanced leaf production in ginger. The high percentage of humic acids in vermicompost contribute to plant health, as it promotes the synthesis of phenolic compounds such as anthocyanins and flavonoids may improve the quality and act as a preventive for pest and diseases which eventually resulted in the production of higher and healthy leaves with higher leaf area (Theunissen et al., 2010).

\section{Table 1. Effect of organic manures and bio-stimulants on growth and yield of ginger}

\begin{tabular}{|c|c|c|c|c|c|c|}
\hline Treatments & Plant height (cm) & $\begin{array}{c}\text { No. of leaves per } \\
\text { plant }\end{array}$ & $\begin{array}{c}\text { No. of tillers per } \\
\text { plant }\end{array}$ & $\begin{array}{l}\text { Leaf area } \\
\left(\mathrm{cm}^{2}\right)\end{array}$ & $\begin{array}{l}\text { Green rhizome } \\
\text { yield (t/ha) }\end{array}$ & Dry recovery (\%) \\
\hline$T_{0}$ & 52.70 & 93.49 & 5.10 & 1786.51 & 12.16 & 13.76 \\
\hline $\mathrm{T}_{1}$ & 47.60 & 92.87 & 5.90 & 1790.49 & 16.00 & 16.06 \\
\hline $\mathrm{T}_{2}$ & 44.84 & 89.64 & 5.10 & 1462.23 & 13.16 & 14.24 \\
\hline $\mathrm{T}_{3}$ & 49.60 & 109.84 & 7.00 & 1763.48 & 17.00 & 14.14 \\
\hline $\mathrm{T}_{4}$ & 56.90 & 137.62 & 7.60 & 2067.16 & 20.16 & 12.15 \\
\hline $\mathrm{T}_{5}$ & 54.60 & 127.61 & 6.90 & 1976.39 & 17.66 & 15.87 \\
\hline $\mathrm{T}_{6}$ & 57.40 & 139.58 & 7.30 & 2293.84 & 20.83 & 13.54 \\
\hline $\mathrm{T}_{7}$ & 60.20 & 140.56 & 9.80 & 2378.72 & 23.55 & 17.34 \\
\hline $\mathrm{T}_{8}$ & 52.70 & 134.63 & 8.70 & 2023.55 & 21.66 & 16.38 \\
\hline $\mathrm{T}_{9}$ & 51.50 & 135.83 & 8.20 & 2078.72 & 20.53 & 16.51 \\
\hline MEAN & 52.804 & 120.167 & 7.16 & 1962.11 & 19.67 & 15.00 \\
\hline SEd & 0.8451 & 1.3201 & 0.131 & 43.66 & 0.37 & 0.41 \\
\hline$C D(P=0.05)$ & $1.7756 * *$ & $2.7734 * *$ & $0.275 * *$ & $91.73 * *$ & $0.78 * *$ & $0.86 * *$ \\
\hline
\end{tabular}


Different treatments significantly influenced the mean green rhizome yield. The maximum green rhizome yield (23.55 t/ha) was obtained with the application of $50 \% \mathrm{~N}$ (FYM) $+25 \% \mathrm{~N}$ (Neem cake) $+25 \% \mathrm{~N}$ (Vermicompost) + Azospirillum (5kg/ha) + Panchakavya (3\%). The treatment T7 recorded the highest dry recovery percentage of $17.34 \%$ followed by T9 (16.51\%). The application of FYM in combination with bio-stimulants and bio-fertilizers increased the soil organic matter and improved the soil structure and biological activity. This would have reduced the loss of nitrogen by increasing cation and anion exchange capacities of soil, thereby enhancing the yield of ginger. Another possible reason for pronounced yield improvement in organic treatment might be the sustained availability of nitrogen throughout the growing phase and enhanced carbohydrate synthesis and effective translocation of these in photosynthesis to sink i.e. rhizome while at lower fertility level plant stunted resulting decreased yield. This is in line with the findings of Mizuno (1999) and Singh (2015). Previous studies reported that organic fertilizer improved soil productivity and fertility, which improved yield and quality of such long duration crop as ginger (Roy et al., 2010 and Dinesh et al., 2010). The highest dry recovery percentage will be observed in the application of 50\% N (FYM) $+25 \% \mathrm{~N}$ (Neem cake) + 25\% N (Vermicompost) + Azospirillum (5kg/ha) + Panchakavya (3\%), which may be due to supply of lower nitrogen under organic management, which tend to enhance the synthesis of nitrogen-poor molecules ( e.g. polyphenols, cellulose, starch) instead of the synthesis of nitrogen rich components such as amino acids, proteins or alkaloids which produce an increase in the dry matter content of the product ( Herencia et al., 2011).

Table 2. Effect of organic manures and bio-stimulants on plant uptake of $N, P, K$ and their contents in soil

\begin{tabular}{|c|c|c|c|c|c|c|}
\hline Treatments & $\mathrm{N}$ uptake (kg/ha) & $\begin{array}{l}\text { Final } N \text { availability } \\
\text { in the soil }(\mathrm{kg} / \mathrm{ha})\end{array}$ & P uptake (kg/ha) & $\begin{array}{l}\text { Final } P \text { availability } \\
\text { in the soil }(\mathrm{kg} / \mathrm{ha})\end{array}$ & K uptake (kg/ha) & $\begin{array}{r}\text { Final } \mathrm{K} \\
\text { availability in the } \\
\text { soil }(\mathrm{kg} / \mathrm{ha})\end{array}$ \\
\hline$\overline{T_{0}}$ & 89.92 & 210.3 & 10.7 & 58.4 & 146.12 & 920.0 \\
\hline $\mathrm{T}_{1}$ & 96.02 & 234.7 & 11.1 & 73.5 & 157.19 & 1003.3 \\
\hline $\mathrm{T}_{2}$ & 88.67 & 232.2 & 10.8 & 67.2 & 145.44 & 949.0 \\
\hline $\mathrm{T}_{3}$ & 87.39 & 223.6 & 11.3 & 53.2 & 134.88 & 960.0 \\
\hline $\mathrm{T}_{4}$ & 111.16 & 210.0 & 11.9 & 62.1 & 176.73 & 1030.0 \\
\hline $\mathrm{T}_{5}$ & 103.44 & 218.4 & 12.4 & 62.4 & 165.57 & 979.0 \\
\hline $\mathrm{T}_{6}$ & 108.52 & 229.0 & 13.0 & 61.3 & 165.28 & 933.0 \\
\hline $\mathrm{T}_{7}$ & 119.06 & 235.2 & 13.5 & 58.1 & 197.56 & 1025.0 \\
\hline$T_{8}$ & 107.67 & 206.1 & 12.6 & 56.1 & 174.36 & 971.0 \\
\hline $\mathrm{T}_{9}$ & 110.84 & 208.6 & 14.4 & 68.5 & 175.55 & 909.0 \\
\hline MEAN & 102.27 & - & 12.16 & - & 163.87 & - \\
\hline SEd & 2.35 & - & 0.27 & - & 2.11 & - \\
\hline$C D(P=0.05)$ & 4.93 & - & 0.57 & - & 4.44 & - \\
\hline
\end{tabular}

Various treatments significantly increased the uptake of nitrogen, phosphorus and potassium (Table 2). Maximum uptake of nitrogen $(119.06 \mathrm{~kg}$ $\mathrm{ha}^{-1}$ ) and potassium (197.56 kg ha-1) was found in the application of $50 \% \mathrm{~N}(\mathrm{FYM})+25 \% \mathrm{~N}$ (Neem cake) $+25 \% \mathrm{~N}$ (vermicompost) + Azospirillum (5kg/ha) + panchakavya (3\%) per hectare. However, maximum uptake of Phosphorus (14.35 kg ha-1) was recorded in the application of $50 \% \mathrm{~N}(\mathrm{FYM})+25 \% \mathrm{~N}$ (neem cake) $+25 \% \mathrm{~N}$ (vermicompost) + Azospirillum (5kg/ ha) + humic acid (0.1\%). The total uptake of nitrogen was influenced significantly by organic and inorganic sources of nitrogen. The nitrogen uptake showed an increasing trend with an increase in the proportion of organic manures; there was an improvement in the physical-chemical properties of soil after the harvest due to the application of 100 per cent RDN through farmyard manure and vermicompost. Application of organic manures resulted in an increase in the organic carbon content of the soil and the electrical conductivity.

The increase in ' $\mathrm{P}$ ' uptake may be due to the prevention of phosphorus fixation in the soil and forming the humophospho complex, which is easily assimilated by plants (Sathish and Paramaguru, 2010). Organic phosphorus in soil comprises 30$70 \%$ of the total phosphorus content. Hydrolysis of this organic phosphorus compound is essential for uptake by plants (Bhattacharyya and Ghosh, 2001) and humic acid brought out this hydrolysis (Adani et al., 1998).

The high uptake of ' $\mathrm{K}$ ' due to the application of organic manures may be due to the beneficial effect of organic manures on the reduction of ' $\mathrm{K}$ ' fixation and the interaction of organic manures with clay to release ' $\mathrm{K}$ ' from the non-exchangeable fraction to the available pool (Jambhelkar, 1994). 
Vermicompost application through the increase of the mineral uptake, such as nitrogen and phosphorus, had a positive effect on proper biomass production and subsequently enhanced essential oil content (Arancon et al., 2006; Zaller, 2007). In soil amended with organic manures, bacterial and fungal counts and dehydrogenase activity were higher (Fraser, 1988). Organic manure application stimulated the microbial proliferation and the process related to ' $\mathrm{N}$ ' cycling in soil.

It can be concluded that the growth, yield and nutrient uptake of ginger were increased under the application of organic manures and bio-stimulants. Among the various treatment combination, application of 7.50 tonnes of FYM + $375 \mathrm{~kg}$ of Neem cake +1.25 tonnes of vermicompost + $5 \mathrm{~kg}$ of Azospirillum + panchakavya (3\%) per hectare was superior in terms of improved growth characters, higher marketable rhizome yield and nutrient uptake.

\section{Ethics statement}

No specific permits were required for the described field studies because no human or animal subjects were involved in this research.

\section{Originality and plagiarism}

Authors should ensure that they have written and submit only entirely original works, and if they have used the work and/or words of others, that this has been appropriately cited. Plagiarism in all its forms constitutes unethical publishing behavior and is unacceptable.

\section{Consent for publication}

All the authors agreed to publish the content.

\section{Competing interests}

There were no conflict of interest in the publication of this content

\section{Data availability}

All the data of this manuscript are included in the MS. No separate external data source is required. If anything is required from the MS, certainly, this will be extended by communicating with the corresponding author through corresponding official mail: rchitra@tnau.ac.in

\section{Author contributions}

$\begin{array}{ll}\text { Research grant } & \mathrm{RC} \\ \text { Idea conceptualization } & \mathrm{RC} \\ \text { Experiments } & \mathrm{LV} \\ \text { Guidance } & \mathrm{RC} \\ \text { Writing-original draft } & \mathrm{RC} \\ \text { Writing- reviewing \&editing } & \mathrm{RC}\end{array}$

\section{REFERENCES}

Adani, F., Genevini, P., Zaccheo, P. and G. Zocchi. 1998. The effect of commercial humic acid on tomato plant growth and mineral nutrition. J. Plant Nutrition, 21(3): 561-575.

Anonymous. 2003. Ginger: Its role in xenobiotic metabolism. Indian Council of Medical Research, New Delhi, pp. 33.

Arancon, N.Q., Edwards, C.A., Lee, S. and R. Byrne. 2006. Effects of humic acids from vermicompost on plant growth. European J. Soil. Biol. 42: 65-69

Bartley, J. and A. Jacobs. 2000. Effects of drying on flavour compounds in Australian grown ginger (Zingiber officinale). J. Sci. Food Agric. 80(20): 209-215.

Bhattacharyya, P. and G. Ghosh. 2001. Phosphorus use efficiency in brinjal with FYM and sulphur. J. Indian Soc. Soil Sci. 49: 456-462.

Dinesh, R., Srinivasan, V., Hamja, S. and A. Mahjusha. 2010. Short term incorporation of organic manures and fertilizers influences biochemicals and microbial characteristics of soils under an annual crop turmeric. Bioresource Technol. 101(12): 4697-702

Fraser, D.G. 1988. The environmental effects of conventional, organic and biological farming systems. Biological Agric. and Hort. 5: 223-287.

Grzanna, R., Linmark, L. and C. Frondoza. 2005. Ginger - A herbal medicinal product with broad antiinflammatory actions. J. Med. Food. 8(2):125-132.

Herencia, J.F., Pedro, A.G., Jose, A.R.D. and C. Maqueda. 2011. Comparison of nutritional quality of the crops grown in an organic and conventional fertilized soil. Sci. Hort., XXX: 1-7.

Humphries, E.C. 1956. Modern methods of plant analysis. 1: 468-502.

Jackson, M.L. 1973. Soil Chemical Analysis. Prentice Hall of India Pvt. Ltd., New Delhi. pp: 498.

Jambhelkar, H. 1994. Bio-organic farming. seminar on Development of Agriculture in Andhra Pradesh held on $4^{\text {th }}$ and $5^{\text {th }}$ September.

Khandkar, U.R. and K. B. Nigam. 1996. Effect of farmyard manure and fertility level on growth and yield of ginger (Zingiber officinale). Indian J. Agri. Sci. 66: 549 - 550.

Mizuno, S. 1996. Integrated soil building: Concept and practice. Problems farming under different Agro Climatic Conditions, Organic farming and sustainable agriculture. In: Proceedings of National Seminar held at USA, Bangalore India, pp. 76-89.

Nene, Y.K. 1999. Seed health in ancient medicinal history and its elegance to present day agriculture. Asian Agri. History. 3(3): 18 - 36

Panse, V.G. and Sukhatme, P.V. 1985. Statistical methods for Agricultural workers. Indian Council of Agricultural Research, New Delhi.

Piper, C.S. 1966. Soil and Plant analysis. Hans Publications, Bombay.

Poinker, M.S, Shembekar, R.Z., Copde, N., Batadhare, 
N., Khewale, A. and K. Dongarhar. 2006. Effect of organic manure and biofertilizers on growth and yield of turmeric (Curcuma longa L.). J. Soils and Crops. 16(2): 417-420.

Roy, S.S. and I. K. Hore. 2007. Influence of organic manures on growth and yield of ginger. J. Plantation Crops. 35: 52-55.

Roy, S., Arunachalam, K., Kumar Dutta, B. and A. Arunachalam. 2010. Effect of organic amendments of soil on growth and productivity of three common crops viz. Zea mays, Phaseolus vulgaris and Abelmoschus esculentus. Appl. Soil Ecol. 45: 78-84

Sahay, K.M. and K. K. Singh. 1994. Unit operations of Agricultural Processing, Vikas Publishing House Pvt. Ltd., New Delhi. p.107.

Sarma, I., Phookan, D.B. and S. Boruah. 2011. Effect of organic manures and biofertilizers on yield and economics of cabbage, Brassica oleracea var. capitata. J. Eco-friendly Agric., 6: 6-9.

Sarma, I., Phukon, M. and Roopa Borgohain. 2015. Effect of organic manure, vermicompost and neem cake on growth, yield and profitability of turmeric (Curcuma longa L.) variety- Megha Turmeric-1. Asian J. Bio Sci. 10(2): 133-137

Sathish, G. and P. Paramaguru. 2010. Response of bioregulants on nutrient uptake pattern of turmeric (Curcuma longa L.) cv. BSR 2. Madras Agric. J. 97(10-12):312-314.
Sharma, B.R., Dutta, S., Roy, S., Debnath, S. and M. D. Roy. 2010. The effect of soil physicochemical properties on rhizome rot and wilt disease complex incidence of ginger under hill agro-climatic region of West Bengal. Pl. Pathology J. 26(2): 198-202.

Singh, S.P. 2015. Nutrient supplementation through organic manures for growth and yield of ginger (Zingiber officinale Rosc.). J. Eco-friendly Agric. 10(1): 28-31.

Singh, S.P., Chaudhary, R. and A. K. Mishra. 2009. Effect of different combination of organic manures on growth and yield of ginger (Zingiber officinale Rosc). J. Eco friendly Agric. 4: 22-24.

Singh, V.B. and A. K. Singh. 2007. Effect of types of organic manures and method of nitrogen application on growth, yield and quality of ginger. Environ. \& Ecol. 25: 103 - 105.

Theunissen, J., Ndakidemi, A. and C. P. Laubscher. 2010. Potential of vermicompost produced from plant waste on the growth and nutrient status in vegetable production. Intl. J. Physical Sci. 5(13): 1964-1973

Zaller, J.G. 2007. Vermicompost as a substitute for peat in potting media: Effects on germination, biomass allocation, yields and fruit quality of three tomato varieties. Sci. Hort. 112: 191-199 